\title{
IbM BAGI PERANGKAT KECAMATAN DI KECAMATAN TONDANO TIMUR KABUPATEN MINAHASA
}

\author{
Wensi Ronald Lesli Paat ${ }^{1}$, Jeane Tuilan² ${ }^{2}$ \& Prycilia Pingkan Mamuaja ${ }^{3}$ \\ 1 Program Studi Pendidikan Teknologi Informasi dan Komunikasi, Fakultas Teknik, \\ Universitas Negeri Manado \\ 2Program Studi Pendidikan Pendidikan Bahasa Inggris, Fakultas Bahasa dan Seni, \\ Universitas Negeri Manado \\ 3Program Studi Ilmu Kesehatan Masyarakat, Fakultas Ilmu Keolahragaan, Universitas Negeri Manado \\ wensipaat@unima.ac.id; jeanetuilan@unima.ac.id; pryciliapingkan@unima.ac.id
}

\begin{abstract}
Abstrak
Perkembangan Teknologi informasi mempengaruhi berbagai macam aspek kehidupan manusia, salah satunya dalam mendukukung pengelolaan administrasi dan pelayanan kepada masyarakat. Microsoft Excel merupakan perangkat lunak pengolah data yang digunakan untuk menyelesaikan permasalahan administratif mulai dari yang paling sederhana sampai ke permasalahan yang lebih kompleks. Metode yang digunakan adalah pelatihan dengan pendekatan praktis-aplikatif, praktis dimana peserta mempraktekkan semua teori yang diberikan dan aplikatif karena materi-materi yang diberikan dan dipraktekkan berkaitan erat dengan tugas dan fungsi instansi terkait. Target pelaksanan Pelatihan ini yaitu: (1) Memperoleh gambaran tentang penguasaan fungsi-fungsi Microsoft Excel dalam proses pengadministrasian. (2) Memperoleh keterampilan mengenai penggunaan fungsi-fungsi Microsoft Excel dalam mempermudah pengadministrasian. (3) Menjadikan perangkat Kecamatan lebih kreatif dan inovatif. (4) Menerapkan ilmu yang dimiliki kepada masyarakat. Luaran dari kegiatan ini adalah: (1) Peningkatan pengetahuan dan ketrampilan bagi perangkat Kecamatan dalam menggunakan dan memaksimalkan fungsi-fungsi Microsoft Excel dengan baik. (2)Harapannya, agar supaya perangkat Kecamatan dapat mengoptimalkan kinerja pengadministrasian dalam pelayanan kepada masyarakat. Sasaran kegiatan ini adalah para perangkat Kantor Kecamatan Tondano Timur. Pelaksanaan kegiatan di Kantor Kecamatan Tondano Timur Kabupaten Minahasa dirasakan oleh pelaksana maupun peserta sangat memuaskan. Dengan indikator kehadiran peserta dan antusias peserta pelatihan cukup baik. Hasil dari pelatihan sudah cukup baik. Suasana pelatihan dan tutorial cukup bagus. Hampir semua peserta mengikuti dari awal sampai akhir. Para pejabat terkait sangat mendukung pelaksanaan pengabdian masyarakat yang dilaksanakan oleh pelaksana.
\end{abstract}

Kata Kunci: Microsoft Excel, perangkat kecamatan, Kecamatan Tondano Timur.

\section{PENDAHULUAN}

\section{Analisis Situasi}

Seiring dengan perkembangan era globalisasi, dunia Teknologi Informasi dan Komunikasi juga berkembang dengan pesat dan pada abad 21 ini Teknologi Informasi dan Komunikasi sudah menjadi kebutuhan primer bagi banyak kalangan. Dengan menggunakan Teknologi Informasi dan Komunikasi, suatu proses dan kegiatan dapat dilakukan dengan lebih cepat, mudah dan efisien. Oleh karena itu penguasaan terhadap perangkat teknologi komunikasi perlu diajarkan pada semua tingkatan. Microsoft Excel adalah General Purpose Electronic Spreadsheet yang dapat digunakan untuk mengorganisir, menghitung, menyediakan maupun menganalisa datadata dan mempresentasikannya ke grafik atau diagram. (Cashman, 2016: 4). Kemudahan lain yang diperoleh dari program ini adalah terintegrasinya program Microsoft Excel dengan program aplikasi windows yang lain. Saat anda membuka 
Microsoft Excel maka sebuah buku kerja (woorbook) siap digunakan yang didalamnya terdapat beberapa lembar kerja (worksheet). Microsoft Excel saat ini merupakan aplikasi pengolahan data yang paling banyak digunakan khususnya dalam pengelolaan administrasi. Kecamatan Tondano Timur merupakan salah satu Kecamatan yang ada di Kabupaten Minahasa Provinsi Sulawesi Utara. Kecamatan Tondano Timur menaungi 9 Kelurahan yang berada di ujung timur Kota Tondano yang merupakan Ibukota Kabupaten Minahasa. Dalam pelayanan terhadap masyarakat khususnya dalam pengadministrasian data elektronik, Pemerintah Kecamatan Tondano Timur menggunakan aplikasi Microsoft Excel, akan tetapi fungsi yang digunakan merupakan fungsi standart sebatas mengetik, menjumlah dan membuat tabel. Minimnya pengetahuan tentang penggunaan fungsi-fungsi Microsoft Excel membuat aplikasi itu sendiri tidak dimanfaatkan secara maksimal. Untuk itu perlunya diadakan pelatihan fungsi-fungsi yang ada dalam Microsoft Excel bagi perangkat Kecamatan Tondano Timur.

\section{Target}

Target pelaksanaan Pelatihan Fungsi-fungsi Microsoft Excel Perangkat Kecamatan di Kecamatan Tondano Timur Kabupaten Minahasa yaitu:
a. Memperoleh
gambaran
tentang penguasaan fungsi-fungsi Microsoft Excel dalam proses pengadministrasian.

b. Memperoleh keterampilan dalam mengoptimalkan fungsi aplikasi Microsoft Excel.

c. Menjadikan perangkat Kecamatan lebih kreatif dan inovatif.

d. Menerapkan ilmu yang dimiliki kepada masyarakat.

\section{Luaran}

Untuk memaksimalkan kinerja pelayanan Perangkat Kecamatan di Kecamatan Tondano Timur Kabupaten Minahasa diperoleh berbagai bentuk luaran yaitu:

a. Peningkatan pengetahuan dan ketrampilan bagi perangkat Kecamatan dalam menggunakan dan memaksimalkan fungsi-fungsi Microsoft Excel dengan baik.

b. Harapannya, agar supaya perangkat Kecamatan dapat mengoptimalkan kinerja pengadministrasian dalam pelayanan kepada masyarakat. Sasaran kegiatan ini adalah para perangkat Kantor Kecamatan Tondano Timur.

\section{METODE PELAKSANAAN}

\section{Metode Kegiatan}

Untuk melaksanakan kegiatan ini, maka dilaksanakan secara bermitra antara tim pelaksana yaitu dari dosen Program Studi Pendidikan Teknologi Informasi dan Komunikasi (PTIK) Fakultas Teknik Universitas Negeri Manado dengan Pimpinan Kecamatan Tondano Timur Kabupaten Minahasa. 


\section{Prosedur Pelaksanaan Kegiatan}

Empat tahapan yaitu yang digunakan adalah perencanaan, pelaksanaan/tindakan, evaluasi dan refleksi hasil kegiatan, dan yang terakhir pelaporan hasil kegiatan.

\section{Tahap Perencanaan}

Tahapan ini dilakukan setelah dilaksanakan survey dan analisa situasi terhadap lokasi kegiatan. Kegiatan yang dilakukan pada tahapan ini adalah tim pelaksana berkomunikasi dengan kepala Pimpinan Kecamatan yang akan menjadi mitra untuk membicarakan maksud dan tujuan, serta mekanisme pelaksanaan kegiatan ini. Selain itu juga membicarakan hal-hal teknis yang mengenai pelaksanaan kegiatan. Setelah mengkoordinasikan pelaksanaan kegiatan maka tim pelaksana menyusun program pelatihan atau workshop. Selain itu juga pada tahapan ini dilakukan pengumpulan alat dan bahan yang akan digunakan.

\section{Pelaksanaan Pelatihan}

Sebelum pelaksanaan kegiatan inti dilakukan, maka dilakukan persiapan terlebih dahulu yaitu pengecekan kembali seluruh peralatan yang akan digunakan serta melakukan diskusi singkat terkait pengadministrasian berkas yang dihadapi. Pelaksanaan pelatihan atau workshop dikerjakan sesuai dengan program yang telah dibuat. Pelatihan atau workshop yang dimaksudkan direncanakan akan diadakan dalam 3 bagian, yaitu: (1) Pengenalan aplikasi Microsoft Excel secara umum; (2) Pembahasan fungsi-fungsi Microsoft Excel yang berhubungan dengan tatakelola pengadministrasian data-data kecamatan; (3) Mengintegrasikan fungsi-fungsi Microsoft Excel dengan menggunakan data-data real yang sering ditemui terkait fungsi pelayanan perangkat di Kantor Kecamatan. Untuk melaksanakan kegiatan tersebut digunakan beberapa metode pelatihan.

\section{Evaluasi dan Refleksi}

Pelaksanaan evaluasi terhadap peserta, sehingga dapat diketahui sejauh mana pemahaman peserta terhadap apa yang diberikan. Evaluasi juga dilakukan terhadap tingkat pemahaman peserta secara teori dan praktek. Refleksi dilakukan terhadap sejauhmana tingkat keberhasilan kegiatan yang telah dilaksanakan. Selain itu juga bertujuan untuk mengetahui kekurangan dan kelebihan dari kegiatan-kegiatan yang telah dilaksanakan dalam rangka untuk menetapkan rekomendasi terhadap keberlangsungan atau pengembangan kegiatan-kegiatan berikutnya. Dengan kata lain ada tindak lanjut program yang sama.

\section{Pelaporan Hasil Kegiatan}

Setelah pelaksanaan kegiatan selesai, maka dibuat pelaporan dari hasil kegiatan yang telah dilaksanakan sebagai bukti pertanggungjawaban terhadap instansi yang menugaskan, bahwa kegiatan telah dilaksanakan. 


\section{HASIL DAN PEMBAHASAN}

Pelaksanaan kegiatan ini diawali dengan menyusun beberapa alternatif pemecahan masalah. Ada beberapa alternatif yang dapat dilakukan dalam memecahkan permasalahan yang dihadapi, yaitu:

a. Pimpinan Kecamatan dalam hal ini Camat mewajibkan staf terkait untuk menguasai fungsi-fungsi Microsoft Excel dalam pengadministrasian berkas/datadata yang ada di Kantor Kecamatan.

b. Pemerintah menyediakan staf ahli dibidang IT.

c. Kepada perangkat Kecamatan diberikan kursus dan pelatihan singkat mengenai bagaimana memaksimalkan fungsifungsi Microsoft Excel dengan benar.

Pada dasarnya semua alternatif tersebut di atas dapat ditempuh, tetapi bila dipertimbangkan lebih jauh dari berbagai segi, seperti kesiapan para perangkat, dana yang dapat disediakan, motivasi dari para pemuda itu sendiri dan lain-lain, maka alternatif yang ketiga dirasa lebih tepat untuk dipilih dan dilaksanakan, terutama dalam jangka pendek karena yang dikehendaki adalah perubahan yang segera diwujudkan. Bila alternatif pertama yang dipilih, persoalannya adalah apakah para perangkat Kecamatan memiliki pengetahuan dasar tentang Microsoft Excel, apakah fasiltas untuk menguasai Microsoft Excel telah tersedia dengan baik, apakah wawasan dan motivasi yang kini dimiliki memadai, dan apakah para perangkat serta pemerintah Kecamatan itu sendiri memiliki 84 dana penunjang untuk itu?. Jika alternatif ketiga yang dipilih, persoalannya adalah apakah pemerintah dapat segera menyediakan dana yang diperlukan untuk pembayaran honor staf ahli atau untuk pengangkatan PNS, perlu juga mengingat moratorium pengangkatan PNS yang sedang gencargencarnya dilakukan.

Berdasarkan pertimbangan-pertimbangan tersebut, maka alternatif ketigat dipandang lebih tepat untuk dipilih, dengan beberapa alasan sebagai berikut :

a. Para perangkat tidak harus meninggalkan aktivitasnya dalam waktu yang cukup lama.

b. Untuk kebutuhan pelatihan, para perangkat tidak perlu mengeluarkan biaya pelatihan, malah mendapatkan bantuan seperlunya untuk bahan-bahan yang diperlukan.

c. Adanya lembaga pendidikan yang sanggup melaksanakan kegiatan ini (Program Studi PTIK Fakultas Teknik UNIMA) yang memili tenaga profesional dalam bidangnya.

d. Dari percakapan dengan pimpinan di Kecamatan Tondano Timur sebelum dilaksanakan pelatihan ini, menunjukkan bahwa pemerintah sangat tertarik dan berkeinginan untuk melaksanakan pelatihan ini.

Jadi pemecahan masalahnya adalah dengan melaksanakan pelatihan dan kursus singkat secara langsung di lokasi atau wilayah yang menjadi sasaran kegiatan ini. Cara ini dimaksudkan untuk mengubah 
kondisi yang ada sekarang ini kepada kondisi yang diharapkan yaitu adanya perluasan pengetahuan, keterampilan, motivasi, kreativitas serta inovatif yang memung- kinkan perangkat dapat memaksimalkan penggunaan aplikasi Microsoft Excel secara tepat dan benar.

Tabel 1. Kondisi yang ada dan yang diharapkan.

\begin{tabular}{|c|c|c|}
\hline KONDISI YANG ADA & PELATIHAN SINGKAT & $\begin{array}{l}\text { KONDISI YANG } \\
\text { DIHARAPKAN }\end{array}$ \\
\hline $\begin{array}{l}\text { Perangkat hanya } \\
\text { menggunakan fungsi- } \\
\text { fungsi standart Microsoft } \\
\text { Excel karena minimnya } \\
\text { pengetahuan, } \\
\text { keterampilan, kreativitas } \\
\text { tentang aplikasi Microsoft } \\
\text { Excel itu sendiri }\end{array}$ & $\begin{array}{l}\text { Faktor-faktor penunjang: } \\
\text { - } \quad \text { Adanya dosen Unima yang profesional } \\
\text { yang siap melaksanakan pelatihan } \\
\text { - } \quad \begin{array}{l}\text { Tingginya antusias perangkat untuk } \\
\text { mengikuti pelatihan singkat ini }\end{array} \\
\text { - } \quad \begin{array}{l}\text { Adanya sambutan yang baik dari pihak } \\
\text { pemerintah setempat. }\end{array} \\
\text { Faktor-faktor penghambat : } \\
\text { - } \quad \text { Keterbatasan waktu, baik pada pihak } \\
\text { pelaksana (Dosen Unima), maupun } \\
\text { pihak peserta } \\
\text { Belum maksimalnya fasilitas yang } \\
\text { menunjang pelaksanaan kegiatan } \\
\text { pelatihan ini } \\
\text { Sulit mendapat fasilitas dalam jumlah } \\
\text { yang cukup banyak secara gratis untuk } \\
\text { digunakan dalam pelatihan ini }\end{array}$ & $\begin{array}{l}\text { Adanya perluasan } \\
\text { pengetahuan, } \\
\text { keterampilan, motivasi, } \\
\text { kreativitas serta } \\
\text { inovatif yang } \\
\text { memungkinkan peserta } \\
\text { dapat memaksimalkan } \\
\text { penggunaan aplikasi } \\
\text { Micrsoft Excel secara } \\
\text { tepat dan benar. }\end{array}$ \\
\hline
\end{tabular}

Dengan memanfaatkan faktor-faktor penunjang yang ada, serta mengendalikan faktor-faktor penghambat seperti digambarkan diatas, maka diharapkan kegiatan pelatihan ini dapat memberikan hasil yang optimal. Kegiatan pengabdian pada masyarakat ini dilaksanakan berdasarkan :

a. Surat tugas dari Pimpinan Fakultas dalam hal ini Dekan Fakultas Teknik Universitas Negeri Manado.

b. Persetujuan lisan dari Camat Kecamatan Tondano Timur Kabupaten Minahasa perihal pelaksanaan pelatihan ini.

Dengan dasar tersebut, kegiatan program pengabdian pada masyarakat ini, telah dilaksanakan mulai dari tahap persiapan, tahap pelaksanaan, sampai tahap pelaporan. Yang dilaksanakan pada tahap persiapan adalah menyiapkan tim pelaksana. Dalam pelaksanaan kegiatan ini, dosen dibantu 1 orang mahasiswa Fakultas Teknik Program Studi PTIK UNIMA.

Metode yang digunakan adalah dengan presentasi, tanya jawab, demonstrasi, pemberian tugas, dan studi kasus. Pada akhir pelaksanaan pelatihan, diberikan kesempatan kepada setiap peserta untuk memberikan tanggapan terhadap pelaksanaan pelatihan ini serta memberikan pemahaman tentang bahan pelatihan yang sudah diikuti sehingga lewat tanggapan-tanggapan tersebut dapat 
dijadikan bahan penilaian untuk melihat tingkat keberhasilan dari pelatihan yang sudah diberikan.

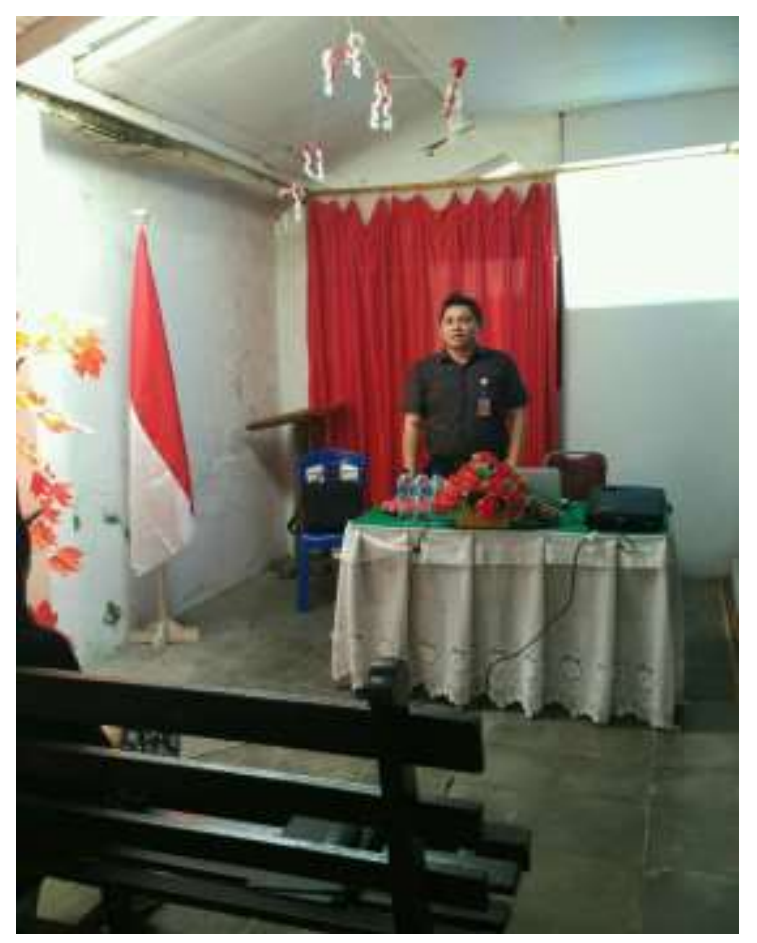

Gambar 1. Presentasi oleh narasumber dalam kegiatan pelatihan.

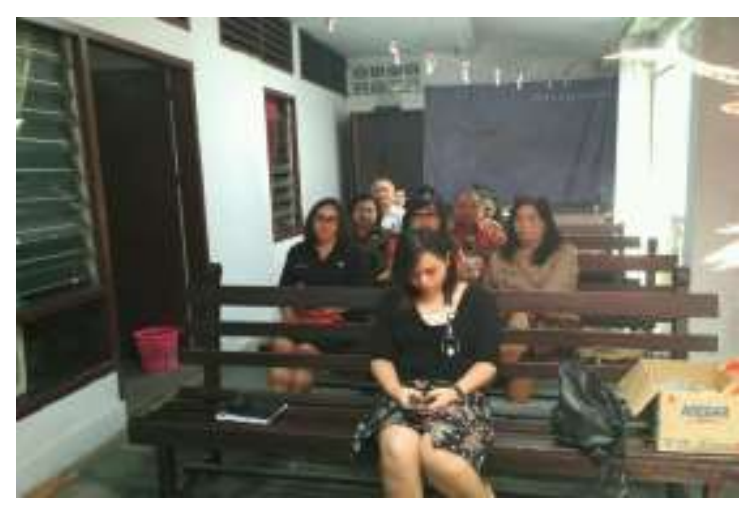

Gambar 2. Peserta kegiatan pelatihan.

Untuk menilai menilai sejauh mana keberhasilan pelaksanaan kegiatan program pelatihan ini, telah dilakukan evaluasi terhadap peserta. Evaluasi dilakukan selama kegiatan dengan memberikan beberapa tugas yang harus dikerjakan oleh semua peserta dan melakukan tanya jawab. Semua hasil tugas dan hasil tanya jawab dijadikan sebagai bahan penilaian keberhasilan pelatihan yang telah dilaksanakan. Seluruh hasilnya dirangkum sebagai berikut :

a. Adanya respon positif dari pemerintah kecamatan khususnya aparat terkait

b. Peserta telah menunjukkan kesungguhan dalam mengikuti pelatihan ini dari awal kegiatan sampai pada akhir kegiatan.

c. Peserta sangat antusias, hal tersebut nampak jelas ketika peserta mempraktekan materi pelatihan yang diberikan

d. Peserta menjadi lebih kreatif dan inovatif

e. Para peserta mengakui bahwa pelatihan ini sangat perlu karena selama ini mereka hanya menggunakan fungsifungsi dasar Microsoft Excel yang tidak dapat secara optimal menyelesaikan masalah-masalah yang di temui.

f. Para peserta berhasil mengerjakan latihan-latihan yang diberikan

g. Para peserta pada umumnya menyatakan bahwa mereka merasa beruntung memperoleh kesempatan mengikuti pelatihan ini, dan mereka mengharapkan Unima untuk melaksanakan kegiatan lanjutan

h. Para peserta menyatakan terima kasih kepada pelaksana. 


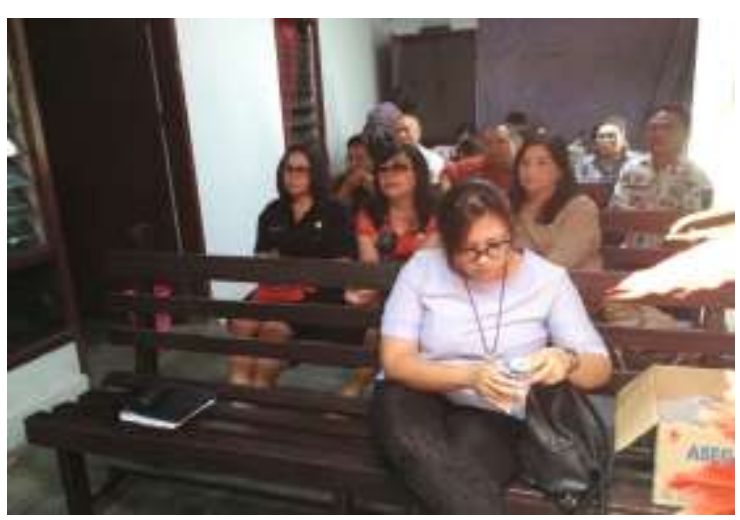

Gambar 3. Peserta kegiatan pelatihan.

Dari penjelasan diatas, maka dapat dikemukakan beberapa hal sebagai berikut :

a. Pelatihan fungsi-fungsi Microsoft Excel bagi perangkat Kecamatan Tondano Timur yang walaupun singkat pelaksanaannya tetapi dapat mendorong tumbuhnya keterampilan, motivasi, kreativitas, serta inovatif dalam pekerjaan sehari-hari khusunya dalam mengelola data Kecamatan;

b. Teknologi informasi dalam hal ini penggunaan Microsoft Excel sangat penting dalam menunjang pekerjaan terkait dengan pelayanan masyarakat yang prima;

c. Program Studi PTIK Fakultas Teknik UNIMA sangat dibutuhkan diberbagai bidang guna meningkatkan kualitas berbagai bidang di Sulawesi Utara.

\section{KESIMPULAN DAN SARAN}

\section{Kesimpulan}

1) Kegiatan pengabdian masyarakat ini berbentuk pelatihan singkat fungsifungsi Microsoft Excel kepada para perangkat Kecamatan Tondano Timur
Kabupaten Minahasa telah berhasil dilaksanakan dengan baik dan mencapai tujuan yang diharapkan

2) Kegiatan ini dapat membantu perangkat dalam mengolah data secara optimal untuk dapat memberikan pelayanan terbaik terhadap masyarakat

3) Kegiatan ini sebagai uasaha pemerataan IPTEKS di daerah Sulawasi Utara, dimana teknologi bukan hanya diperuntukan oleh masyarakat kota besar

4) Kegiatan ini merupakan bagian dari upaya peningkatan kualitas aparatur negara sebagai abdi masyarakat.

5) Kegiatan ini telah memberikan kontribusi bagi LPPM UNIMA untuk mempertimbangkan dalam menetapkan program-programnya diwaktu yang akan datang.

\section{Saran}

1) Kegiatan pengabdian kepada masyarakat seperti ini perlu dilajutkan dengan materi dan kegiatan yang sama tapi dapat dilaksanakan ditempat yang berbeda, ataupun materi yang berbeda ditempat yang sama.

2) Hubungan kerja sama antara UNIMA dengan pemerintah mulai dari pemerintah Provinsi sampai pemerintah Desa/ Kelurahan melalui Lembaga Pengabdian Masyarakat yang selama ini telah terjalin perlu ditingkatkan dan diperluas dalam menangani permasalahan 
yang berhubungan dengan teknologi informasi.

3) Setiap tenaga akademik di Perguruan Tinggi (Dosen) khusunya UNIMA hendaknya peka terhadap kondisi masyarakat serta persoalan yang ada didalamnya, dengan cara memberikan solusi-solusi yang bermanfaat dan berdampak positif.

\section{KEPUSTAKAAN}

Arigin, Johan. 2013. Aplikasi Excel Untuk Akuntansi Manajemen Modern, Jakarta : Penerbit Elex Media Komputindo
Cashman, S. 2016. Microsfot Offcie 365:Introductory. Michigan : Sin Vandy Publishing Co.

Cashman, S.. 2016. Discovering Computers \& Microsfot Offcie 2013. Michigan : Vermaat Publishing Co.

Purnomo, C.H. 2009120 Tip \& Trik Menggunakan Microsoft Office Excel 2007, Jakarta Timur : Penerbit Media Kita

Supriansyah, H. 2008. Buku Pintar Microsoft Excel, Bandung : Penerbit OASE MEDIA. 